\title{
Garnet peridotite xenoliths in alkali basalts from Siberia and Mongolia: a comparison of lithospheric mantle compositions in cratonic and younger terrains
}

Ionov, D.A., Griffin, W.L., O’Reilly, S.Y.

GEMOC, School of Earth Sciences, Macquarie University, Sydney, 2109 N.S.W., Australia

Garnet peridotite xenoltihs occur in Cenozoic alkali basaltic rocks in southern Siberia and Mongolia south of the Siberian craton. Bulk major element compositions and mineral analyses were obtained for large garnet and spinel peridotite xenoliths from the Vitim volcanic field east of lake Baikal and from the Dariganga volcanic field in SE Mongolia. Trace element composition of garnet, pyroxenes and accessory minerals were determined by laser-ablation ICP-MS. The results are considered in comparison with literature data on peridotite xenoliths from Yakutian kimberlites to examine differences between cratonic and younger lithospheric mantle in Asia and elsewhere.

The garnet-bearing rocks range from garnet-spinel peridotites with spinel mantled by garnet to spinelfree garnet peridotites. The garnet peridotites are commonly protogranular coarse-grained rocks with large garnet grains; typical garnet contents are 5-10\% for xenoliths from SE Mongolia and 10-15\% for xenoliths from Vitim. The garnet peridotites from SE Mongolia equilibrated at 22-26 kbar (Nickel and Green, 1985) and $1090-1150^{\circ} \mathrm{C}$ (Brey and Köhler, 1990), those from Vitim equilibrated largely at 19$22 \mathrm{kbar}$ and $980-1040^{\circ} \mathrm{C}$ and some yield evidence for heating before entrainment in host magma. These P-T estimates indicate elevated regional geotherms compared with a much "colder" geotherm defined by xenoliths from the Siberian craton (Boyd et al., 1997). T estimates for spinel peridotites range from $850^{\circ} \mathrm{C}$ to values similar to those of garnet peridotites.

The garnet peridotites have moderate to high contents of clinopyroxene and garnet and of "basaltic" major oxides $\left(\mathrm{CaO}, \mathrm{Al}_{2} \mathrm{O}_{3}, \mathrm{Na}_{2} \mathrm{O}\right)$. Spinel peridotites may have more depleted compositions than garnet peridotites (Fig. 1A) with similar equilibration temperatures. This suggests that in the pressure range of 20-26 kbar relatively fertile garnet lherzolites coexist with more depleted spinel peridotites. Both garnet and spinel peridotites from SE Mongolia tend to be more depleted in basaltic components that those from the Baikal region (Fig. 1B) apparently indicating differences in bulk peridotite mantle compositions between the two regions that may be related to differences in geological history. In general, however, mantle xenoliths from these and most other occurrences in southern Siberia and Mongolia provide a strong geochemical contrast with more depleted and more magnesian mantle beneath the Siberian Platform to the north sampled by kimberlites (Fig. 1B). In particular, the $\mathrm{Mg} /(\mathrm{Mg}+\mathrm{Fe})_{\text {at }}$ ratios of the majority of xenoliths in alkali basalts (0.89-91) are much lower than those of low-T garnet peridotites from the Yakutian kimberlites (Boyd et al., 1997).

Clinopyroxenes in garnet lherzolites from the Vitim field (Ionov et al., 1993) and SE Mongolia typically show light to moderate depletion in LREE (Fig. 2A) and other incompatible trace elements. Modally and cryptically metasomatised garnet-bearing peridotites occur in both regions but are less common than the LREE-depleted rocks. In contrast, low-T spinel peridotites enriched in light and 
medium REE over the heavy REE appear to be more common than those depleted in LREE in SE Mongolia (Fig. 2B). This may indicate a regional chemical stratification of the mantle with more widespread metasomatic enrichment in the shallow spinel facies mantle.

These results further illustrate the large differences in the composition of subcontinental lithospheric mantle between the cratonic and younger terrains (Pearson et al., 1995) and may provide evidence for secular mantle evolution and long-term crust-mantle coupling. The combination of the non-refractory compositions and the moderately high geothermal gradient in the mantle in southern Siberia and Mongolia may be responsible for generally lower seismic velocities right below the Moho in that region than in the Siberian craton.
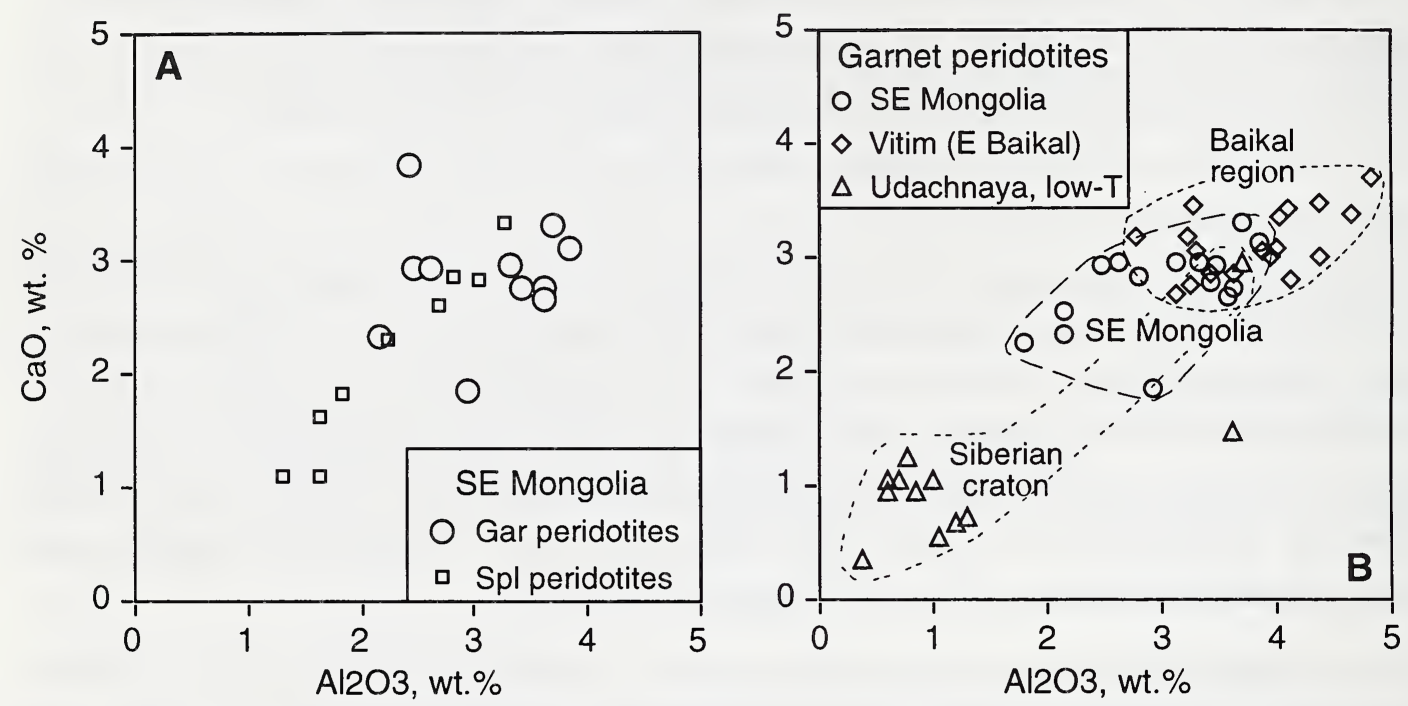

Fig. 1. Plots of $\mathrm{CaO}$ vs. $\mathrm{Al}_{2} \mathrm{O}_{3}$ for garnet and spinel peridotites from SE Mongolia (A) and for garnet peridotites from SE Mongolia, Baikal region and Udachnaya (B) (Boyd et al., 1997).

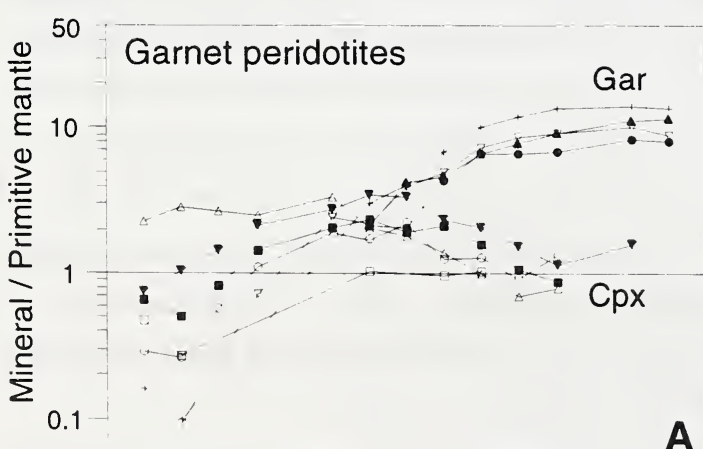

La Ce Pr Nd SmEuGdTb DyHo ErTmYb Lu

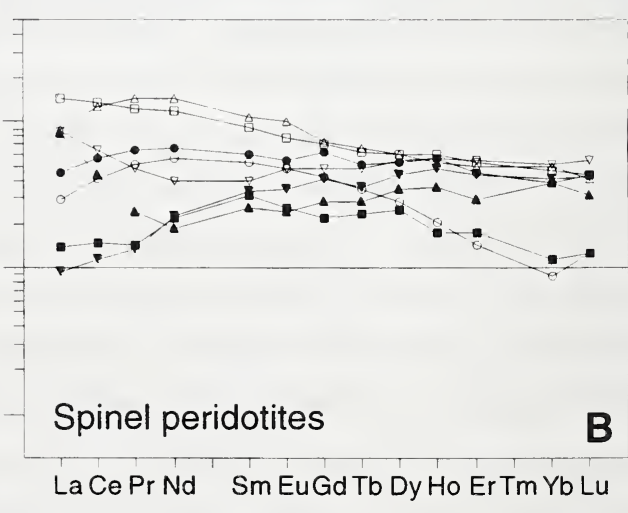

Fig. 2. Primitive mantle-normalised (Hofmann, 1988) REE patterns for minerals of peridotite xenoliths from SE Mongolia: (A) clinopyroxene and garnet from garnet peridotites; (B) clinopyroxene from spinel peridotites. 


\section{References}

Boyd, F.R., Pokhilenko, N.P., Pearson, D.G., Mertzman, S.A., Sobolev, N.V., and Finger, L.W., 1997, Composition of the Siberian cratonic mantle: evidence from Udachnaya peridotite xenoliths: Contib. Mineral. Petrol., p. 228-246.

Brey, G., and Kohler, T., 1990, Geothermobarometry in four-phase lherzolites II. New thermobarometers, and practical assessment of existing thermobarometers: J. Petrol., 31, p. 1353-1378.

Hofmann, A., 1988, Chemical differentiation of the Earth: the relationship between mantle, continental crust, and oceanic crust: Earth Planet. Sci. Lett., 90, p. 297-314.

Ionov, D., Ashchepkov, I., Stosch, H.-G., Witt-Eickschen, G., and Seck, H, 1993, Garnet peridotite xenoliths the Vitim volcanic field, Baikal region: the nature of the garnet-spinel peridotite transition zone in the continental mantle: J. Petrol, 34, 6, p. 1141-1175.

Nickel, K., and Green, D., 1985, Empirical geothermobarometry for garnet peridotites and implications for the nature of the lithospere, kimberlites and diamonds: Earth Planet. Sci. Lett., 18 , p. $158-170$.

Pearson, D.G., Carlson, R.W., Shirey, S.B., Boyd, F.R., and Nixon, P.H., 1995, Stabilisation of Archaen lithospheric mantle: A Re-Os isotope study of peridotite xenoliths from the Kaapvaal craton: Earth Planet. Sci. Lett., 134, p. 341-357. 